\title{
Lead and iron absorption from rat small intestine: the effect of dietary Fe deficiency
}

\author{
BY I. K. ROBERTSON AND M. WORWOOD \\ Department of Haematology, Welsh National School of Medicine, \\ Cardiff $\mathrm{CF}_{4} 4 \mathrm{XN}$
}

(Received 25 October 1977 - Accepted 23 January 1978)

I. When lead is administered in drinking-water iron-deficient rats retain more $\mathrm{Pb}$ than Fe-replete rats (Six \& Goyer, I972; Klauder \& Petering, 1975). In the present study the relationship between the absorption of $\mathrm{Pb}$ and $\mathrm{Fe}$ was investigated.

2. Adult male rats were transferred to a milk-based diet fed with or without supplementary Fe (I $80 \mathrm{mg}$ $\mathrm{Fe} / \mathrm{kg}$ as ferrous sulphate). After $7-9 \mathrm{~d}$ the absorption of duodenally-administered ${ }^{203} \mathrm{~Pb}$ and ${ }^{50} \mathrm{Fe}$ was measured as uptake of radioactivity from the gastrointestinal tract after $90 \mathrm{~min}$. ${ }^{59} \mathrm{Fe}$ absorption was increased in rats given the unsupplemented diet for $7 \mathrm{~d}$ and was further increased in rats kept on the diet for up to 7 weeks. ${ }^{208} \mathrm{~Pb}$ absorption was not consistently increased by either short- or long-term Fe deprivation.

3. Much of the ${ }^{203} \mathrm{~Pb}$ in homogenates of the upper small intestine was bound to soluble protein of which up to $85 \%$ was dialysable. In contrast little ${ }^{80} \mathrm{Fe}$ was dialysable. Only a small proportion of the soluble musosal $\mathrm{Pb}$ was associated with ferritin during gel-filtration chromatography although ${ }^{203} \mathrm{~Pb}$ precipitated together with carrier rat-liver ferritin with an antibody to rat-liver ferritin.

4. There appeared to be no direct relationship between the transfer of $\mathrm{Fe}$ and $\mathrm{Pb}$ across the small intestine of the adult rat.

The human body contains approximately I $20 \mathrm{mg}$ lead of which $90 \%$ is in the skeleton (Schroeder \& Tipton, 1969). Pb enters the body from the gastrointestinal tract and through the lungs. The adult diet includes approximately $260 \mu \mathrm{g} \mathrm{Pb} / \mathrm{d}$ with drinking-water providing an additional small amount (Schroeder \& Tipton, 1969). Organic $\mathrm{Pb}$ compounds in the air, especially lead tetraethyl, are important sources of $\mathrm{Pb}$ for absorption through the lungs and $30-50 \%$ of the $30-40 \mu \mathrm{g} \mathrm{Pb}$ inhaled daily is retained (Kehoe, 1969).

$\mathrm{Pb}$ poisoning is most common in children from $\mathrm{I}$ to 3 years old (Browder, Joselow \& Louria, 1973) and iron deficiency is often associated with $\mathrm{Pb}$ poisoning in such children. Rats placed on diets deficient in Fe accumulate more $\mathrm{Pb}$ in the tissues than rats on a normal diet (Six \& Goyer, 1972; Klauder \& Petering, 1975) and Kochen \& Greener (I975) suggested that binding of $\mathrm{Pb}$ to ferritin in the Fe-replete intestinal mucosa reduces $\mathrm{Pb}$ absorption compared with that in Fe-deficient rats. However, little information is available about the mechanism of $\mathrm{Pb}$ absorption from the gut. This paper reports on $\mathrm{Pb}$ absorption from the upper small intestine in normal and Fe-deficient rats and on the subcellular distribution of $\mathrm{Pb}$ in the small intestine during its absorption.

\section{EXPERIMENTAL}

Rats. Adult, male Wistar rats were 8-10 weeks old at the time of the absorption measurements except for rats in group A (Table 1 ) which were 13 weeks old. The rats were given a milk-based diet (McCall, Newman, O'Brien, Valberg \& Witts, I962; Triggs \& Bailey-Wood, 1976) for 7-9 d before the study. This diet contained either no added Fe salt or ferrous sulphate at a concentration of $\mathrm{I} 80 \mathrm{mg} \mathrm{Fe} / \mathrm{kg}$. The $\mathrm{Pb}$ content of the diet was $0.2 \mathrm{mg} / \mathrm{kg}$. Preliminary studies were carried out with rats fed on the milk-based diet for $6 \mathrm{~d}$ (see p. 255). Three groups of rats (groups A, B and C) were then studicd (see Table I). The rats within a group were of the same age. Groups $B$ and $C$ included rats which were given the unsupple- 


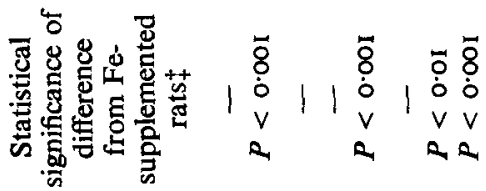

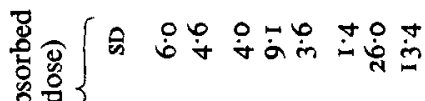

密 造

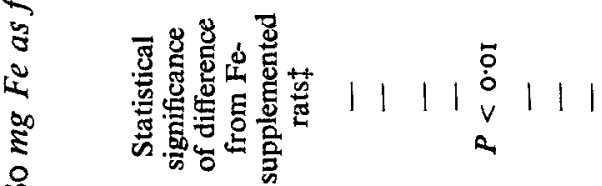

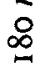

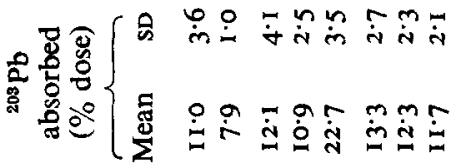

o

בิ)

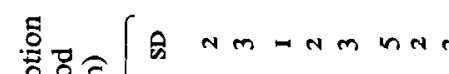

․․‥

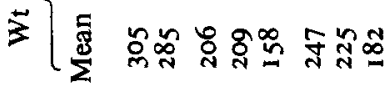

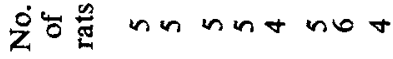

2



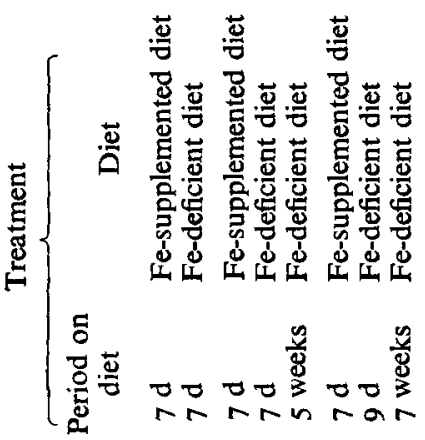

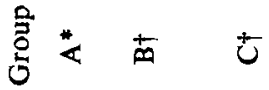


mented (Fe-deficient) diet from the time of weaning until absorption measurements were carried out 5 or 7 weeks later. The remaining rats received a normal diet (Pilsbury's Modified Rat Breeding diet; Pilsbury, 2 I Priory Road, Birmingham B5 7 UG) but were transferred to the milk-based diet 7-9 d before the study.

Preliminary studies of $\mathrm{Pb}$ absorption. Rats were given solutions of lead acetate $\left(\mathrm{IO}^{-4} \mathrm{M}\right)$, labelled with ${ }^{203} \mathrm{PbCl}_{2}$, by means of a stomach tube. The animals were housed singly in metabolism cages for periods of I, 3, 6 or $20 \mathrm{~h}$. Animals were anaesthetized with diethyl ether and killed by exsanguination. Radioactivity was measured in the carcass after removal of the intestines, in washings from the small intestine, upper, middle and lower segments of washed small intestine, in blood, and in urine using counting techniques described later (p. 255).

Feeding solutions. These contained lead acetate $\left(\mathrm{IO}^{-4}\right.$ or $\left.\mathrm{IO}^{-5} \mathrm{M}\right)$ and ferric chloride ( $10^{-4} \mathrm{M}$ or $2.5 \times 10^{-5} \mathrm{M}$ ) in $0.05 \mathrm{M}$-hydrochloric acid labelled with ${ }^{203} \mathrm{~Pb}\left(4 \mu \mathrm{Ci}\right.$ as $\left.\mathrm{PbCl}_{2} / \mathrm{ml}\right)$ and ${ }^{59} \mathrm{Fe}(4 \mu \mathrm{Ci}$ as ferric chloride $/ \mathrm{ml}) .{ }^{203} \mathrm{PbCl}_{2}$ was supplied by the $\mathrm{MRC}$ Cyclotron Unit, Hammersmith, London and ${ }^{59} \mathrm{FeCl}_{3}$ was obtained from the Radiochemical Centre, Amersham, Bucks.

Absorption of $\mathrm{Pb}$ and $\mathrm{Fe}$ from the small intestine. A rat was anaesthetized with diethyl ether and a small-diameter polyethylene tube was passed into the stomach. The abdomen was opened with a mid-line incision and the stomach and duodenum were exposed. The polyethylene tube was moved into the duodenum and a thread was tied around the small intestine just below the pylorus. Care was taken to avoid ligating any major blood vessels. Feeding solution $(\mathrm{I} \mathrm{ml})$ was passed into the duodenum, followed by $0.5 \mathrm{ml}$ saline $(9 \mathrm{~g}$ sodium chloride/l). The tube was withdrawn from the duodenum as the ligature was tied and then the tube was withdrawn through the mouth. After replacing the intestine and covering the incision the rat remained anaesthetized for a further $90 \mathrm{~min}$. The rat was then killed by exsanguination and the blood was collected for determination of the haemoglobin concentration with Drabkin's reagent. The entire gastrointestinal tract was removed and the mucosa was expressed from the first $400 \mathrm{~mm}$ small intestine (Worwood \& Jacobs, 1971). The mucosa was separated by differential centrifugation into five subcellular fractions (Worwood \& Jacobs, 1971).

Measurement of ${ }^{203} \mathrm{~Pb}$ and ${ }^{59} \mathrm{Fe}$. Absorption was defined as the percentage of the dose remaining in the carcass after removal of the whole gastrointestinal tract. Radioactivity was determined with an animal radioisotope counter consisting of a $\mathrm{Pb}$-shielded ring of eight geiger-tubes with a quench probe unit and scaler. Initial experiments showed that the same counting rate was obtained when $\mathrm{I} \mathrm{ml}$ feeding solution was counted as such or after feeding to a rat. Counting rates were corrected for 'resolving-time' losses and background and were therefore proportional to radioactivity. The feeding solution and the carcasses were recounted after an interval of several days and the initial contributions to the total radioactivity due to ${ }^{203} \mathrm{~Pb}$ and ${ }^{59} \mathrm{Fe}$ calculated by means of the following equations:

$$
\begin{aligned}
\mathrm{Pb}_{0} & =\frac{x e^{-\lambda \mathrm{Fe}^{t}}-y}{e^{-\lambda_{\mathrm{Fe}} t}-e^{-\lambda_{\mathrm{Pb}} t}}, \\
\mathrm{Fe}_{0} & =x-\mathrm{Pb}_{0},
\end{aligned}
$$

where $\mathrm{Pb}_{0}$ and $\mathrm{Fe}_{\mathrm{o}}$ are the true counting rates of ${ }^{203} \mathrm{~Pb}$ and ${ }^{59} \mathrm{Fe}$ respectively at the first count, $x$ is the corrected counting rate at that time, $y$ is the corrected counting rate at the time of the second count $t \mathrm{~h}$ later, $\lambda_{\mathrm{Fe}}$ and $\lambda_{\mathrm{Pb}}$ are the decay constants for ${ }^{59} \mathrm{Fe}$ and ${ }^{203} \mathrm{~Pb}$.

The ${ }^{203} \mathrm{~Pb}$ and ${ }^{59} \mathrm{Fe}$ contributions to the activity of small volumes of solution or suspension (e.g. column fractions) were measured with an automatic gamma counter fitted with two- 
channel electronics (LKB-Wallac, Croydon, Surrey). ${ }^{59} \mathrm{Fe}$ activity was measured with an energy setting which did not allow the inclusion of any contribution from ${ }^{203} \mathrm{~Pb}$ and solutions of ${ }^{59} \mathrm{Fe}$ were used to calculate the percentage of the ${ }^{59} \mathrm{Fe}$-channel counts recorded in the lowerenergy ${ }^{203} \mathrm{~Pb}$ channel. The counting rate in this lower channel was then corrected to give the rate due to ${ }^{203} \mathrm{~Pb}$ only.

Binding of $\mathrm{Pb}$ and $\mathrm{Fe}$ to the soluble fraction of mucosal homogenates. Portions of the soluble fraction obtained by differential centrifugation were subjected to chromatography on Sepharose 6 B (Pharmacia (GB) Ltd, 75 Uxbridge Road, London $\mathrm{W}_{5} 5 \mathrm{SS}$ ) in $0.02 \mathrm{M}$ Tris- $\mathrm{HCl}$ buffer, $\mathrm{pH} 7.5$. The column was $900 \mathrm{~mm} \times 16 \mathrm{~mm}$ and $3 \mathrm{ml}$ fractions were collected. The columns were calibrated with Blue Dextran (Pharmacia (GB) Ltd); rat-liver ferritin prepared as described by Worwood, Aherne, Dawkins \& Jacobs (1975) and rat transferrin prepared by the procedure of Sullivan, Grasso \& Weintraub (1976). An antiserum to rat-liver ferritin was prepared by injecting rabbits three times with $\mathrm{I}$ mg protein with Freund's complete adjuvant at intervals of 2 weeks. Blood was collected after a further 2 weeks.

\section{RESULTS}

${ }^{203} \mathrm{~Pb}$ and ${ }^{59} \mathrm{Fe}$ absorption. Preliminary studies indicated that the dose absorbed up to $20 \mathrm{~h}$ after feeding ${ }^{203} \mathrm{~Pb}$ by stomach tube was extremely variable. After washing the small intestine, radioactivity was greatest in the upper small intestine and urinary excretion was negligible (a maximum of $0.2 \%$ dose). The absorption of ${ }^{203} \mathrm{~Pb}$ after $20 \mathrm{~h}$ was compared in two groups of nine rats: one group was given the Fe-supplemented diet for $6 \mathrm{~d}$ before the absorption test and the other group the Fe-deficient diet for the same period; mean $( \pm S D)$ values for absorptions were $13 \pm 9$ and $17 \pm 14 \%$ respectively. Large variation was apparent and there was no significant difference in absorption between the two groups. It was therefore decided to measure absorption directly from the small intestine by administering radioactivity to the duodenum. The results obtained are summarized in Table I. Feeding the rats an Fedeficient diet for only $7 \mathrm{~d}$ increased $\mathrm{Fe}$ absorption and absorption increased further with the chronically Fe-deficient rats. However, an increased $\mathrm{Pb}$ absorption could only be demonstrated in one group of rats (group B, Fe-deficient diet for 5 weeks) and such an increase was not found in the other group of chronically-Fe-deficient rats (group C).

${ }^{203} \mathrm{~Pb}$ and ${ }^{59} \mathrm{Fe}$ in the intestinal mucosa. From $9-20 \%$ dose of ${ }^{203} \mathrm{~Pb}$ or ${ }^{59} \mathrm{Fe}$ administered was present in the mucosa from the first $400 \mathrm{~mm}$ of small intestine after $90 \mathrm{~min}$. There was no significant effect of $\mathrm{Fe}$ status on ${ }^{203} \mathrm{~Pb}$ uptake. The subcellular distributions of ${ }^{203} \mathrm{~Pb}$ and ${ }^{59} \mathrm{Fe}$ in homogenates of pooled mucosas are illustrated in Fig. I. The ${ }^{59} \mathrm{Fe}$ distribution compared well with results of previous studies (Worwood \& Jacobs, I97I, 1972) and the increased mitochondrial concentration of ${ }^{59} \mathrm{Fe}$ in the mucosa from Fe-deficient rats (fraction no. 3, Fig. I) was noticeable. Like ${ }^{59} \mathrm{Fe},{ }^{203} \mathrm{~Pb}$ was mainly concentrated in the soluble fraction with up to $50 \%$ of the radioactivity in this fraction (fraction no. 6). Up to $85 \%$ of this soluble ${ }^{203} \mathrm{~Pb}$ was dialysable against saline-0.02 $\mathrm{M}$-Tris- $\mathrm{HCl}$ buffer solution, $\mathrm{pH} 7.5$, but only $13 \%$ of ${ }^{59} \mathrm{Fe}$ could be removed by exhaustive dialysis. Gel filtration on Sepharose 6B was carried out on the soluble fraction (Fig. 2). In mucosal extracts from Fe-supplemented rats ${ }^{59} \mathrm{Fe}-$ activity was largely associated with protein eluting at the same volume as rat-liver ferritin (maximum in fraction nos. 32-33), whereas in the mucosal extracts from the rats given the Fe-deficient diet for 7-9 d the majority of the activity was associated with protein having the same elution volume as rat plasma transferrin (fraction no. 4I). After 5-7 weeks on the Fe-deficient diet there was very little activity associated with the ferritin region. Previous studies (Worwood, I977) have shown that almost all the soluble $\mathrm{Fe}$ is bound to either ferritin (Fe-replete cells) or an intracellular transferrin (Fe-deficient cells). The ${ }^{203} \mathrm{~Pb}$ distribution was different; much of the radioactivity was associated with protein of molecular weight 

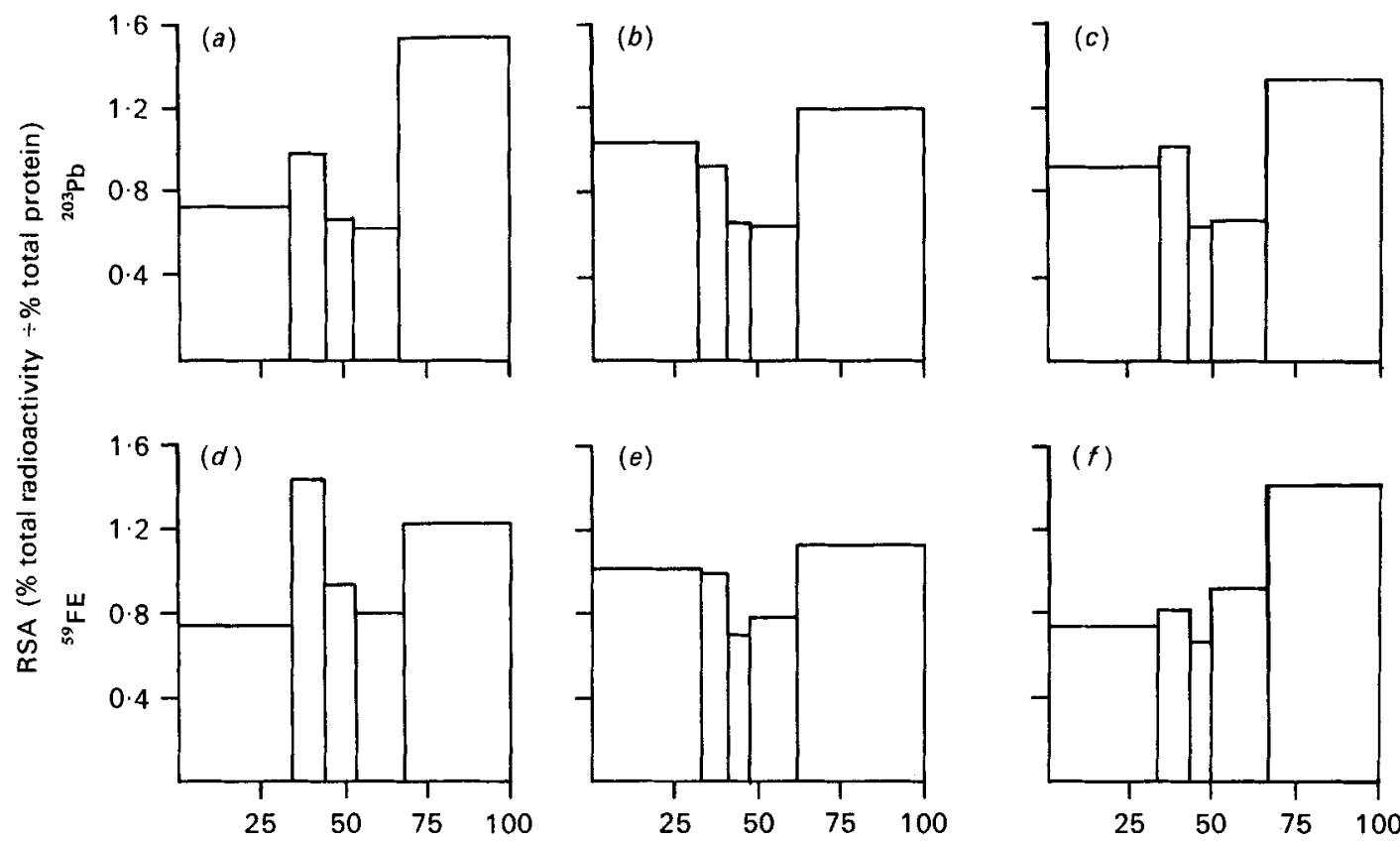

Protein content (\% total protein content of homogenate)

\author{
Fraction no... $2 \quad 2 \quad 34 \quad 5 \quad 6$
}

$\begin{array}{llll}2 & 34 & 5 & 6\end{array}$

$2 \quad 345$

6

Fig. I. Subcellular distribution of ${ }^{203} \mathrm{~Pb}$ and ${ }^{59} \mathrm{Fe}$ activities in homogenates of intestinal mucosa from rats of group B (see Table I) given a milk-based diet. The distribution is expressed as relative specific activity (RSA; \% total homogenate radioactivity in a fraction $\div \%$ total protein content in that fraction). The protein contents of fractions nos. 2-6 are expressed as \% total protein content of the homogenate. Subcellular fractions were: 2 , nuclear; 3, mitochondrial; 4, lysosomal; 5, microsomal; 6, soluble. $(a, d)$, Rats given the unsupplemented (Fe-deficient) diet for 5 weeks; $(b, e), \mathrm{Fe}$ deficient diet for $7 \mathrm{~d} ;(c, f)$, supplemented with $180 \mathrm{mg} \mathrm{Fe}$ as ferrous sulphate $/ \mathrm{kg}$.

between that of ferritin (460000) and transferrin (80000) and eluted with maximum activity in fractions nos. 35-36 in both Fe-supplement and Fe-deficient rats (Fig. 2). The results shown in Fig. 2 were obtained with rats of group C. A similar ${ }^{203} \mathrm{~Pb}$ distribution was noted with rats of group B and with the rats fed with the Fe-deficient diet for 5-7 weeks (groups $\mathrm{B}$ and $\mathrm{C}$ ). However, much of the ${ }^{203} \mathrm{~Pb}$ activity was dialysable and chromatography of the activity remaining showed that only a small proportion of the total radioactivity could be associated with ferritin or transferrin. However, after the addition of carrier rat-liver ferritin ( $50 \mu \mathrm{g}$ protein) to I $\mathrm{ml}$ portions of mucosal supernatant fractions and precipitation with rabbit anti-rat-liver ferritin approximately $50 \%$ of ${ }^{203} \mathrm{~Pb}$ activity was precipitated. These studies were carried out with rats on the Fe-supplemented diet. Although the gelfiltration studies suggest some association of ${ }^{203} \mathrm{~Pb}$ with the transferrin-like protein, precipitation with anti-transferrin was not carried out.

\title{
DISCUSSION
}

The aim of this experimental study was to investigate any relationship between $\mathrm{Fe}$ and $\mathrm{Pb}$ transfer across the small intestinal epithelium. To avoid interaction between the $\mathrm{Fe}$ and $\mathrm{Pb}$ solutions and stomach contents the solutions were directly administered to the small intestine thus reducing the considerable variation in absorption of ${ }^{203} \mathrm{~Pb}$ and ${ }^{50} \mathrm{Fe}$ found when the dose was given by stomach tube. Advantage was also taken of the finding by Pollack, Kaufman 

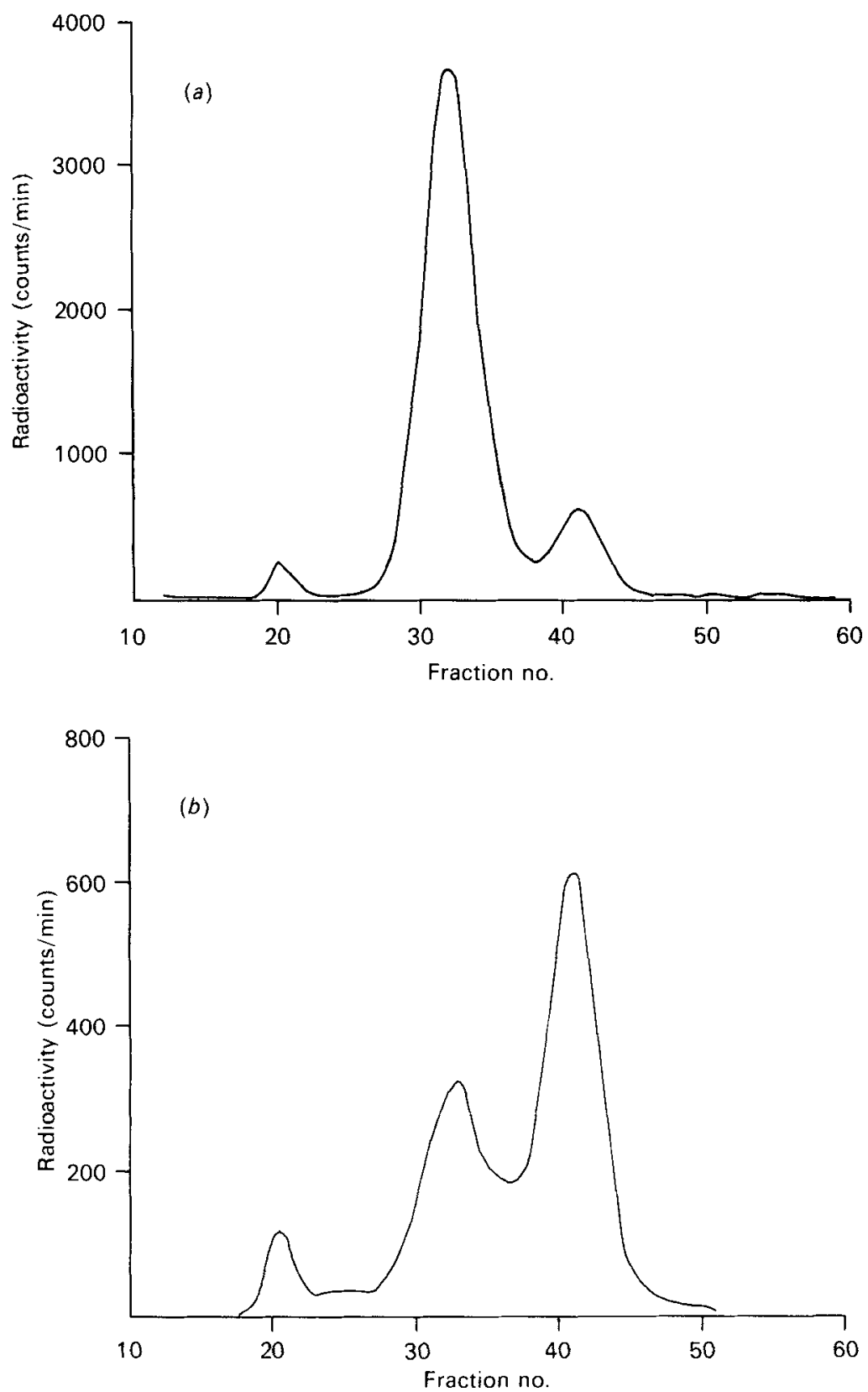

Fig. 2. Gel filtration on Sepharose 6B of the soluble fraction from the intestinal mucosa of rats receiving ${ }^{59} \mathrm{Fe}$ and ${ }^{203} \mathrm{~Pb}$ duodenally and given a milk-based diet with or without $180 \mathrm{mg} \mathrm{Fe}$ as ferrous sulphate $/ \mathrm{kg}$. (a), ${ }^{59} \mathrm{Fe}$ activity, Fe-supplemented diet; $(b),{ }^{59} \mathrm{Fe}$ activity, unsupplemented (Fe-deficient) diet for $9 \mathrm{~d}$; (c), ${ }^{203} \mathrm{~Pb}$ activity, Fe-supplemented diet; $(d),{ }^{203} \mathrm{~Pb}$ activity, Fe-deficient diet for $9 \mathrm{~d} ;(A)$, before dialysis; $(B)$, after dialysis. For further details of ${ }^{203} \mathrm{~Pb}$ and ${ }^{59} \mathrm{Fe}$ absorption in these groups of rats see group C (Table I). The volume collected in each fraction was $3 \mathrm{ml}$. 

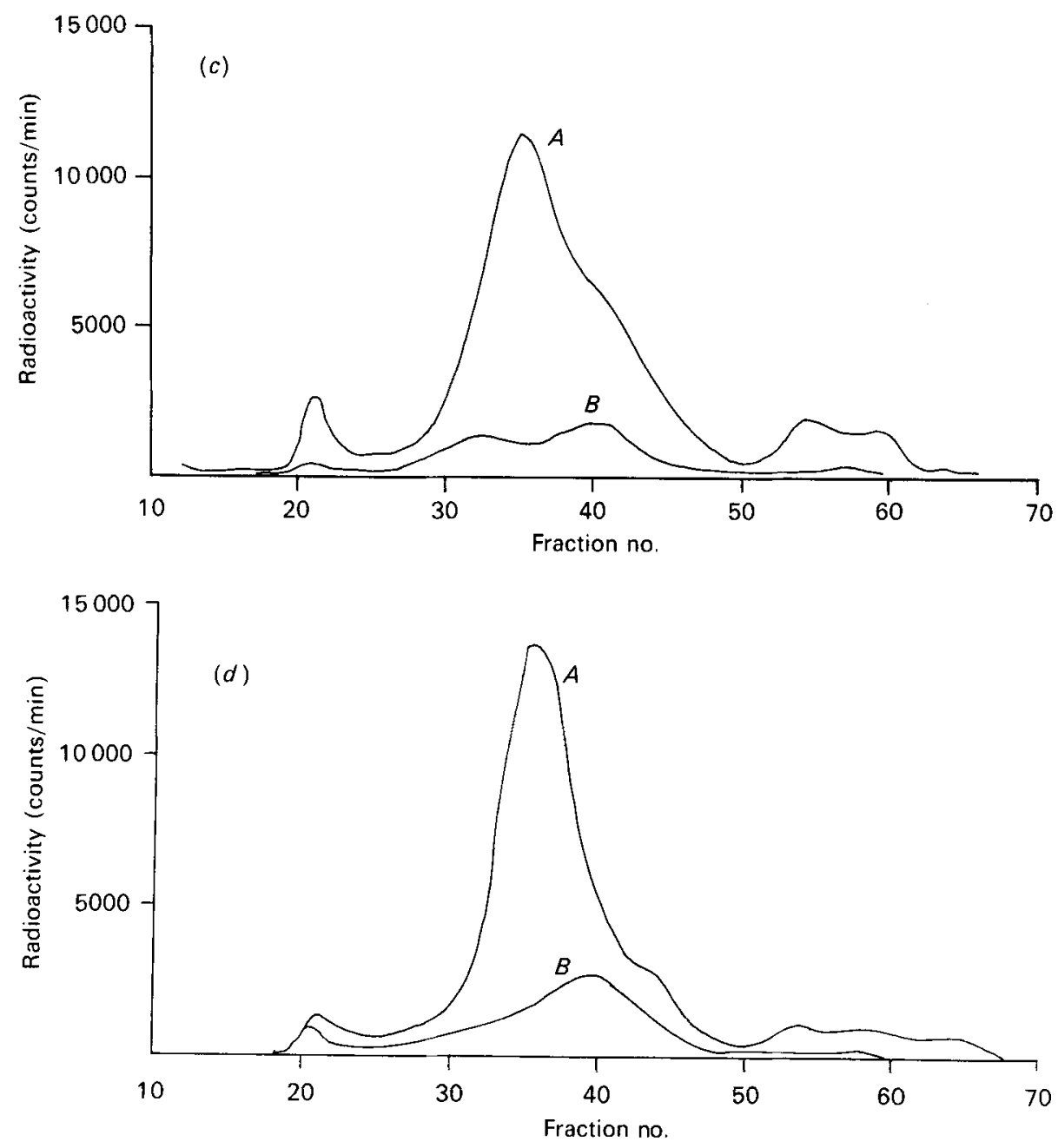

Figs. $2(c)$ and $(d)$. For legend see opposite.

\& Crosby (1964) that within a few days of placing rats on a diet deficient in Fe there is an increase in Fe absorption. This made it possible to increase Fe absorption in the absence of the widespread metabolic changes associated with Fe-deficiency anaemia. If there is any direct relationship between the intracellular transport of $\mathrm{Fe}$ and $\mathrm{Pb}$ it might be expected that an increase in $\mathrm{Pb}$ absorption would occur in both short- and long-term Fe deficiency. We were, however, unable to demonstrate a consistent increase in ${ }^{203} \mathrm{~Pb}$ absorption in rats with increased $\mathrm{Fe}$ absorption even in rats given an Fe-deficient diet for 7 weeks. It should be noted that the control rats for these long-term studies only received the milk-based diet for $7 \mathrm{~d}$ before the absorption test.

The intracellular transport of $\mathrm{Pb}$ was also very different to that of $\mathrm{Fe}$. Although much of the mucosal ${ }^{59} \mathrm{Fe}$ and ${ }^{203} \mathrm{~Pb}$ was associated with soluble protein, $\mathrm{Fe}$ was almost entirely bound to either ferritin or a mucosal transferrin (see also Worwood, 1977) with very little dialysable ${ }^{59} \mathrm{Fe}$. In contrast, $\mathrm{Pb}$ was bound to proteins of molecular weight between that of ferritin and transferrin and more than $80 \%$ of the soluble mucosal ${ }^{203} \mathrm{~Pb}$ could be removed by dialysis. Only a small proportion of the soluble ${ }^{203} \mathrm{~Pb}$ was therefore associated with either 
ferritin or transferrin. ${ }^{203} \mathrm{~Pb}$ can be precipitated with an excess of rat-liver ferritin and this may explain the results reported by Kochen \& Greener (1975), who suggested that binding to ferritin in Fe-replete rats would inhibit $\mathrm{Pb}$ absorption. It also suggests that binding to ferritin in vivo may be significant in tissues with high concentrations of ferritin, for example the liver.

The results described in this paper suggested that the mechanism of $\mathrm{Pb}$ absorption is very different from that of $\mathrm{Fe}$ absorption and that a direct action of Fe deficiency on $\mathrm{Pb}$ absorption at the intestinal mucosa is unlikely to be the cause of the increased retention of $\mathrm{Pb}$ observed with Fe-deficient rats. Obviously, the number of animals studied does not allow the detection of small changes in $\mathrm{Pb}$ absorption but examination of the results of Six \& Goyer (1972) suggests that a large increase in $\mathrm{Pb}$ absorption would be needed to bring about the threefold increase in the $\mathrm{Pb}$ content of the bone described in their study. Chronic Fe deficiency affects the synthesis of Fe-containing proteins but also leads to widespread metabolic abnormalities (Dallman, 1974). It is necessary to examine the intra-luminal binding of $\mathrm{Pb}$ in the stomach and small intestine, the transport of $\mathrm{Pb}$ within the body and its excretion in order to understand the reasons for the accumulation of $\mathrm{Pb}$ in $\mathrm{Fe}$-deficient animals.

The authors thank the Blood Research Fund for a grant to I.K. R., also Professor A. Jacobs for his encouragement and Mr G. M. Owen of the Department of Medical Physics, University Hospital of Wales, for advice and assistance with the isotope counting.

\section{REFERENCES}

Browder, A. A., Joselow, M. M. \& Louria, D. B. (1973). Medicine 52, I 21.

Dallman, P. (1974). In Iron in Biochemistry and Medicine, p. 437 [A. Jacobs and M. Worwood, editors]. London and New York: Academic Press.

Kehoe, R. A. (1969). J. Air Pollut. Control Ass. 19, 9.

Klauder, D. S. \& Petering, H. G. (1975). Envir. Hlth. Persp. 12, 77.

Kochen, J. \& Greener, Y. (1975). Pediat. Res. 9, 323.

McCall, M. G., Newman, G. E., O'Brien, J. R. P., Valberg, L. S. \& Witts, L. J. (I962). Br. J. Nutr. r6, 297.

Pollack, S., Kaufman, R. M. \& Crosby, W. H. (I964). Science, N.Y. 144, 1015.

Schroeder, H. \& Tipton, I. H. (I 969). Archs Envir. Hlth. 17, 965.

Six, K. M. \& Goyer, R. A. (1972). J. Lab. clin. Med. 79, 128.

Sullivan, A. L., Grasso, J. A. \& Weintraub, L. R. (1976). Blood 47, 133.

Triggs, S. M. \& Bailey-Wood, R. (1976). Br. J. Nutr. 35, 277.

Worwood, M. (1977). Sem. Hemat. 14, 3.

Worwood, M., Aherne, W., Dawkins, S. \& Jacobs, A. (1975). Clin. Sci. mol. Med. 48, 441.

Worwood, M. \& Jacobs, A. (I97I). Br. J. Haemat. 20, 587.

Worwood, M. \& Jacobs, A. (1972). Br. J. Haemat. 22, 265. 